\title{
Notes on two species of Processa (Decapoda: Processidae) from the Mexican Pacific
}

Manuel Ayón-Parente, Michel E. Hendrickx and Eduardo Ríos-Jara

(MEH) Laboratorio de Invertebrados Bentónicos, Unidad Académica Mazatlán, Instituto de Ciencias del Mar y Limnología, Universidad Nacional Autónoma de México. P.O. Box 811, Mazatlán, Sinaloa, 82000. Mexico. E-mail: michel@ola.icmyl.unam.mx

(MAP, ERJ) Departamento de Ecología, CUCBA-Universidad de Guadalajara. Carretera a Nogales. Las Agujas Nextipac, Zapopan, Jalisco, C.P. 45110, Mexico. (MAP) E-mails: manuel_aparente@hotmail. com; (ERJ) eriosjara@gmail.com

\section{Abstract}

Material belonging to the genus Processa, held in the Regional Marine Invertebrates Collection in Mazatlán, Mexico, is revised including specimens of the widely distributed $P$. peruviana, and the scarcely collected $P$. hawaiensis. For comparative purposes with the specimens from Hawaii and other localities, a detailed description of a male of $P$. hawaiensis collected in continental Mexico is provided, including illustrations of all appendages. Small differences are noted with previous description and partial redescriptions of this species, including proportion between propodus and dactylus of the fourth pereopod, and between merus and carpus of the right cheliped. In addition, the shape and setation of the first pair of pleopods in the Mexican material differs from the description of $P$. hawaiensis based on African material.

Key words: Caridea, Mexican Pacific, Processa hawaiensis, P. peruviana,

\section{Introduction}

The caridean shrimp genus Processa Leach, 1815, includes 52 species. The most recently described species is $P$. famelica Manning and Hart, 1991 (De Grave and Fransen, 2011). Of this total number of species, only three have been recorded in the East Pacific: P. aequimana (Paulson, 1875), an Indo-Pacific species collected in the Gulf of California, Mexico; P. peruviana Wicksten, 1983, known from California, USA, to Mancora, Peru, and the Galápagos Islands; P. hawaiensis (Dana, 1852), widely distributed throughout the Indo-Pacific, and recorded from continental Mexico by Álvarez et al. (1996). Processa pippinae Wicksten and Méndez, 1985, a pelagic species endemic to the Gulf of California, Mexico, was recently assigned to a different genus, Maryprocessa (Hendrickx, 2012).

Of the three species occurring along the west-American continent, Processa peruviana is endemic and without any doubt the most frequently reported. It has been repeatedly found in trawls and small dredge samples (see Hendrickx and Wicksten, 2011). It is also the largest species (up to $40 \mathrm{~mm}$ total length) for the area. Processa aequimana was first reported 
for the East Pacific by Wicksten (1983), who noted that despite the similarities with the Indo-Pacific material, the specimens from the East Pacific might belong to a different species once additional material is examined. The other exotic species, $P$. hawaiensis, represents another problem since there are only a few transPacific species of shallow tropical decapod crustaceans that were able to reach continental America from their original distribution area (see Garth, 1946; Hendrickx, 1992, 1995; Hendrickx and Harvey, 1999; Wicksten and Hendrickx, 2003).

Dana (1852) originally described Nika hawaiensis probably based on a unique specimen. Later on, the species was rediscovered in Hawaii by Edmondson (1930, as Processa paucirostris; also cited by Edmondson, 1946). Partial redescriptions of this species, transferred to Processa by Rathbun (1903: 912), were provided by Hayashi (1975; illustrations of habitus, head appendages, third maxilliped, pereopods $2-5$, pleopod 1 endopod, abdominal somites 5-6 and telson in lateral view) and by Álvarez et al. (1996; illustrations of forehead, antennule, third maxilliped, pereopods 1-3, and telson in dorsal view). Several authors (see synonymy) have reported $P$. hawaiensis from widely separated localities, including Clipperton Island (Chace, 1962), East Africa (Zanzibar and Kenya) (Hayashi, 1975), and western Mexico (Álvarez et al., 1996; Hendrickx and Wicksten, 2011).

In order to detect small morphological differences among specimens of widely distributed species collected in different localities, a precise description is needed, preferably using recently collected material. The purpose of this contribution is to provide a thorough description of freshly collected specimens of $P$. hawaiensis from continental western Mexico, and to summarize differences between these specimens and previous descriptions available in literature. Additionally, specimens of $P$. peruviana recently collected in the northern Gulf of California are reported.

\section{Material and Methods}

The material of $P$. hawaiensis was manually collected in the intertidal and subtidal zones along the coast of Nayarit and Jalisco, Mexico. The specimens of $P$. peruviana were obtained while sampling with the R/V "El Puma", UNAM, in the northern section of the central Gulf of California, roughly between $28^{\circ} 10^{\prime}$ and $29^{\circ} 10^{\prime} \mathrm{N}$. Specimens were collected with a $2.35 \mathrm{~m}$ wide by $0.95 \mathrm{~m}$ high, standard benthic sledge, and a $1.80 \mathrm{~m}$ wide by $0.80 \mathrm{~m}$ high modified Agassiz dredge, both equipped with an outer collecting net of ca 5.5 $\mathrm{cm}(21 / 4$ ") stretched mesh and an inner net of ca $2.0 \mathrm{~cm}$ (3/4") stretched mesh. Trawling lasted 30 minutes at an average speed of 1.75 knots. Sampling depths were estimated with a digital SIMRAD echo sounder. Epibenthic temperature and oxygen concentration were measured ca $10 \mathrm{~m}$ above bottom level with a Seabird CTD-O $\mathrm{O}_{2}$ probe. Oxygen concentrations were also double-checked with the Winkler method using water samples collected in closing bottles near bottom. All the specimens are deposited in the Regional Collection of Marine Invertebrates (EMU), Instituto de Ciencias del Mar y Limnología, Universidad Nacional Autónoma de México (UNAM), in Mazatlán, Mexico.

Terminology generally follows that of Manning and Chace (1971) and Manning and Hart (1991). The measurement used is carapace length (CL, in $\mathrm{mm}$ ), from orbit to posterior margin of carapace. To avoid confusion in translating geographic localities where material was collected, all names were used in their original spelling in Spanish.

\section{Results}

Systematics

Order Decapoda Latreille, 1803

Suborder Pleocyemata Burkenroad, 1963

Family Processidae Ortmann, 1896

Genus Processa Leach, 1815 
Processa hawaiensis (Dana, 1852)

(Figs. 1-3)

Nika hawaiensis Dana, 1852: 20; 1852a: 538; 1855, pl.33, fig. 7.- Weitenweber, 1854: 10. Processa hawaiensis. - Rathbun, 1903: 912.- De Man, 1920: 199 (list).- Edmondson, 1935: 5.Chace, 1962: 616. Hayashi, 1975: 106, figs. 22, 23a-j.- Álvarez et al., 1996: 721, fig. 5.

Processa paucirostris Edmondson, 1930: 3, fig. 1; 1946: 248, fig. 148b.- Gurney, 1937: 87 (list).- Manning and Chace, 1971; 13 (list).

Processa hawaiiensis.- Manning and Chace, 1971: 13 (list).

Processa cf. aequimana.- Hendrickx and Wicksten, 2011: 31.

Material examined: Male, $2.7 \mathrm{~mm}$, Isla Cocinas (ca 19³2'09”N, 10505'09”W), Bahía de Chamela, Jalisco, Mexico, $5 \mathrm{~m}$, scuba diving, 26 June 2009 (EMU-9585); 2 males, 2.0-2.2 mm, beach at Punta Mita, near village $\left(20^{\circ} 47^{\prime} 20^{\prime \prime} \mathrm{N}, 105^{\circ} 31^{\prime} 5^{\prime \prime} \mathrm{W}\right)$, rocky intertidal, collected manually, 12 November 2004 (EMU-8834); 1 ovigerous female, $3.2 \mathrm{~mm}$, Isla Cocinas (ca 19³2'09”N, 10505'09”W), Bahía de Chamela, Jalisco, Mexico, $5 \mathrm{~m}$, scuba diving, 26 June 2009 (EMU-9586); 4 males, 1.8-2.2 mm, same locality (EMU-9587); 3 males, 2.5-2.7 mm, El Novillo, Bahía de Chamela, Jalisco, Mexico, $5 \mathrm{~m}$, scuba diving, 28 November 2011 (EMU-9588).

\section{Description of Mexican material collected during this survey}

Rostrum straight, short, reaching proximal one-third of ocular peduncles, ending in simple, acute spine with 2 subdistal very short setae, ventral margin convex (Fig. 1B, C). Carapace with lower orbital angle rounded, inconspicuous; antennal spine present; pterygostomial angle broadly rounded.

Abdomen smooth (Fig. 1A). First to fourth pleura rounded. Fourth to sixth abdominal somites bearing short spiniform setae on dorsal and dorsolateral surfaces; fifth abdominal somite slightly shorter than sixth; pleura of fifth and sixth abdominal somites with posteroventral spine; fifth abdominal sternite (Fig. 1D, E) with a posteriorly curved spine.

Telson (Fig. 1A, D, F, G) about 1.7 times longer than sixth abdominal somite, length about 3 times greatest width; 2 pairs of dorsal and 3 pairs of distal spines, one pair of distal setae; anterior pair of dorsal spines of telson set at end of proximal third, posterior pair slightly beyond midlength; distance between anterior margin and anterior pair of spines about 1.3 times distance between pairs of dorsal spines; inner of distal spines shorter and plumose; dorsal surface with two irregular longitudinal rows of short spiniform setae; apex of telson produced into sharp projection.

Eye (Fig. 1A, B) moderately large; cornea width subequal to length of stalk and cornea combined, slightly more than 2 times greatest width of antennal scale.

Antennular peduncle (Fig. 1B) extending beyond rostrum by distal 2 segments and about 0.75 of proximal segment, latter longer than combined length of distal segments; proximal segment unarmed. Second segment sligthly shorter than third. Stylocerite (Fig. 1H) obtusely rounded laterally, unarmed, rounded distally. Dorsolateral flagellum of antennule as long as carapace; ventromesial flagellum about twice as long as carapace.

Antennal scale (Fig. 1B, I) extending to end of antennular peduncle, length of scale about 4 times longer than wide; distal spine of scale not overreaching blade. Antennal peduncle extending to middle of third segment of antennular peduncle. Basal segment of antenna lacking ventrolateral spine. Antennal flagellum about 5 times as long as carapace.

Third maxilliped (Fig. 2G, H) overreaching antennal scale by ultimate 2 segments; ultimate segment slightly longer than penultimate, apex acute; dorsomesial margin with 2 strong mobile spines, distal spine flanked by 4 smaller spines; mesial surface with short transverse rows of short bristles; 


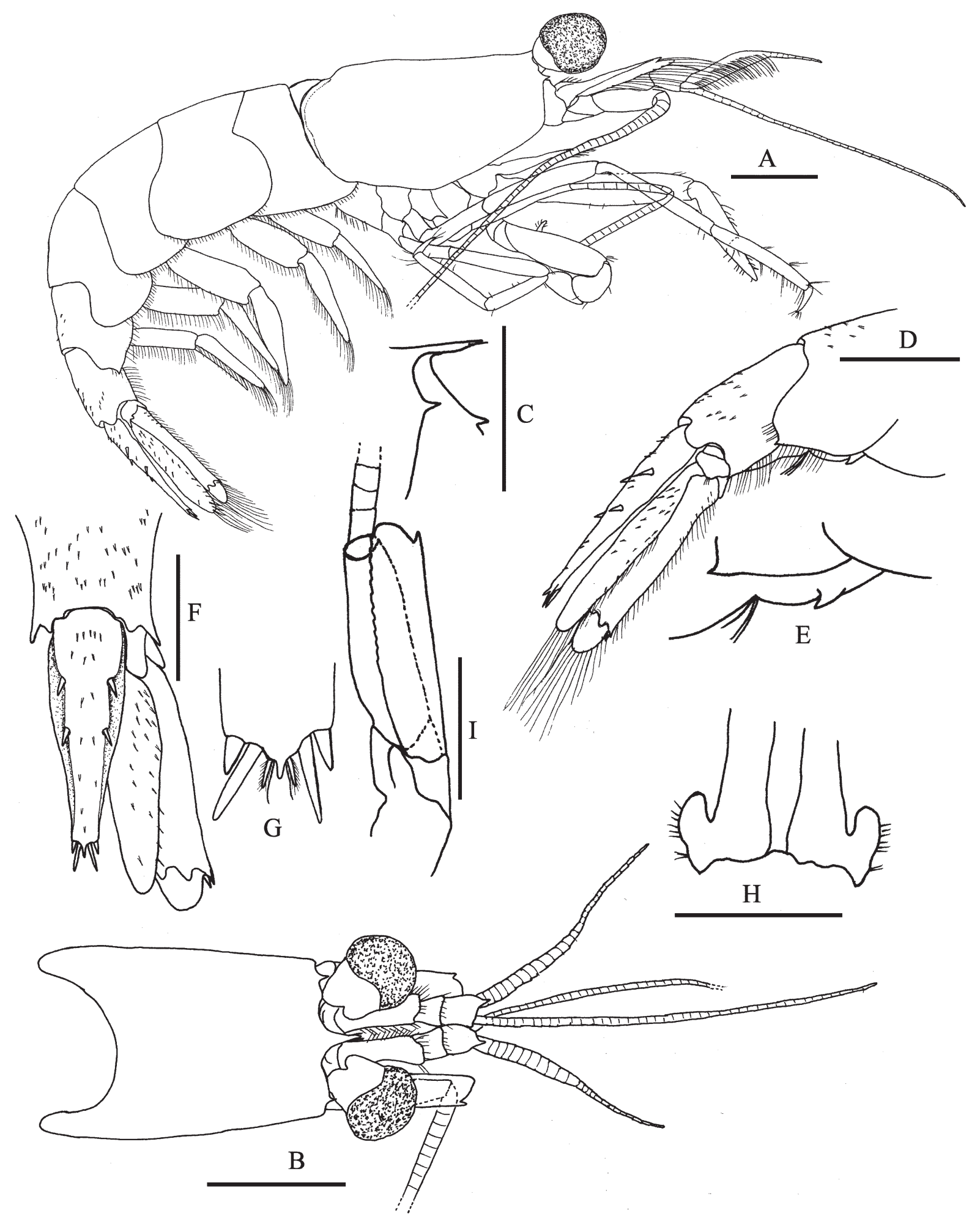

Figure 1. Processa hawaiensis, male $2.7 \mathrm{~mm}$ (EMU-9585). (A) Lateral view; (B) Anterior region of carapace and cephalic appendages, dorsal view; (C) Rostrum, lateral view; (D) Abdominal somites 5-6, telson and right uropods, lateral view; (E) Detail of abdominal sternite 5, lateral view; (F) Sixth abdominal somite, telson and right uropods, dorsal view; (G) Magnification of the telson; (H) Details of stylocerites, removed, dorsal view; (I) Right antenna, dorsal view. Scale bars, $1 \mathrm{~mm}$. 
dorsolateral margin with strong mobile spine on proximal fourth; lateral surface with edge of carina bearing row of small spines, posterior spines larger than others; penultimate segment with 2 mobile spines at dorsodistal margin, inner smaller; exopod rudimentary.

Mandible with 8-9 spines on posterior margin of molar process (Fig. 2A, B); Remaining mouthparts (Fig. 2C-F) similar to those figured by Manning and Chace (1971) for other species of Processa.

First pereopods with merocarpal articulation not extending beyond eye. Right first pereopod chelate (Fig. 3A); fingers about 0.75 length of palm; carpus shorter than palm; merus almost as long as carpus and chela combined. Left first pereopod (Fig. 3B) with simple dactyl, about 0.33 as long as propodus; carpus about 0.67 as long as propodus; merus almost as long as distal segments combined.

Second pereopods - asymetrical, right (Fig. 3C) longer than left, reaching distal third of antennal scale; merus with 7-9, and carpus with 17-19 articles; fingers as long as palm; carpus about 5 times as long as chela; merus 3 times as long as chela. Merus and carpus of left pereopod (Fig. 3D) with 5-7 and 1114 articles, respectively; fingers about 0.67 length of palm; carpus 4 times as long as chela; merus about 2.50 times as long as chela. Ischia of both pereopods bearing 2 to 3 indistinct articulations.

Third pereopod overreaching antennal scale by combined length of dactyl and propodus (Fig. 3E); dactyl slender, simple, with apical setae; propodus 3 times as long as dactyl, unarmed, ornamented with scattered tufts of setae more numerous on ventral margin, longer tufts at apex; carpus 1.30 times as long as propodus, unarmed; merus as long as propodus, with a single subterminal spine on outer surface; ischium shorter than merus, unarmed.

Fourth pereopod overreaching antennal scale by dactyl, propodus, and 0.50 of carpus length; dactyl slender, simple, apex with tufts of setae (Fig. 3F); propodus about 3 times as long as dactyl, unarmed, with some scattered tufts of setae; carpus 1.25 times as long as propodus, unarmed, with scattered setae; merus about 1.20 times as long as propodus, unarmed, with scattered setae on ventral margin; ischium shorter than merus, unarmed; combined length of propodus and carpus of fourth pereopod greater than that of ischium and merus.

Fifth pereopod overreaching antennal scale by length of dactyl (Fig. 3G); dactyl slender, simple, with some apical setae; propodus about 3 times length of dactyl, provided with 9-12 spines on posterior margin; dorsal and ventral margins with scattered tufts of setae; carpus shorter than propodus, unarmed; merus as long as propodus, unarmed; ischium shorter than merus, unarmed; combined length of propodus and carpus slightly greater than that of ischium and merus.

Male endopod of first pleopod about 0.50 as long as exopod, tapering at apex (Fig. 2J). Appendix masculina (Fig. 2I) with 5 distal spines and 3 marginal spinules; appendix interna with 10 diminute distal coupling hooks.

Outer margin of uropodal exopod ending in triangular spine, flanked by longer mesial spine (Fig. 1F); with distinct suture. Endopodal upper surface with some short spiniform setae.

Ovigerous female with small and numerous eggs, $0.35 \mathrm{~mm}$ in diameter.

Color in life unknown.

Distribution in continental Mexico: Known from Isla Isabel $\left(21^{\circ} 50^{\prime} \mathrm{N}, 105^{\circ} 54^{\prime} \mathrm{W}\right)$, Punta Mita, Nayarit $\left(20^{\circ} 47^{\prime} 20^{\prime \prime N}\right.$ $\left.105^{\circ} 31^{\prime} 5^{\prime \prime W}\right)$, and Bahía de Chamela (19³2'09”N - 10505'09”W), Jalisco, Mexico (Alvarez et al., 1996; this study). 


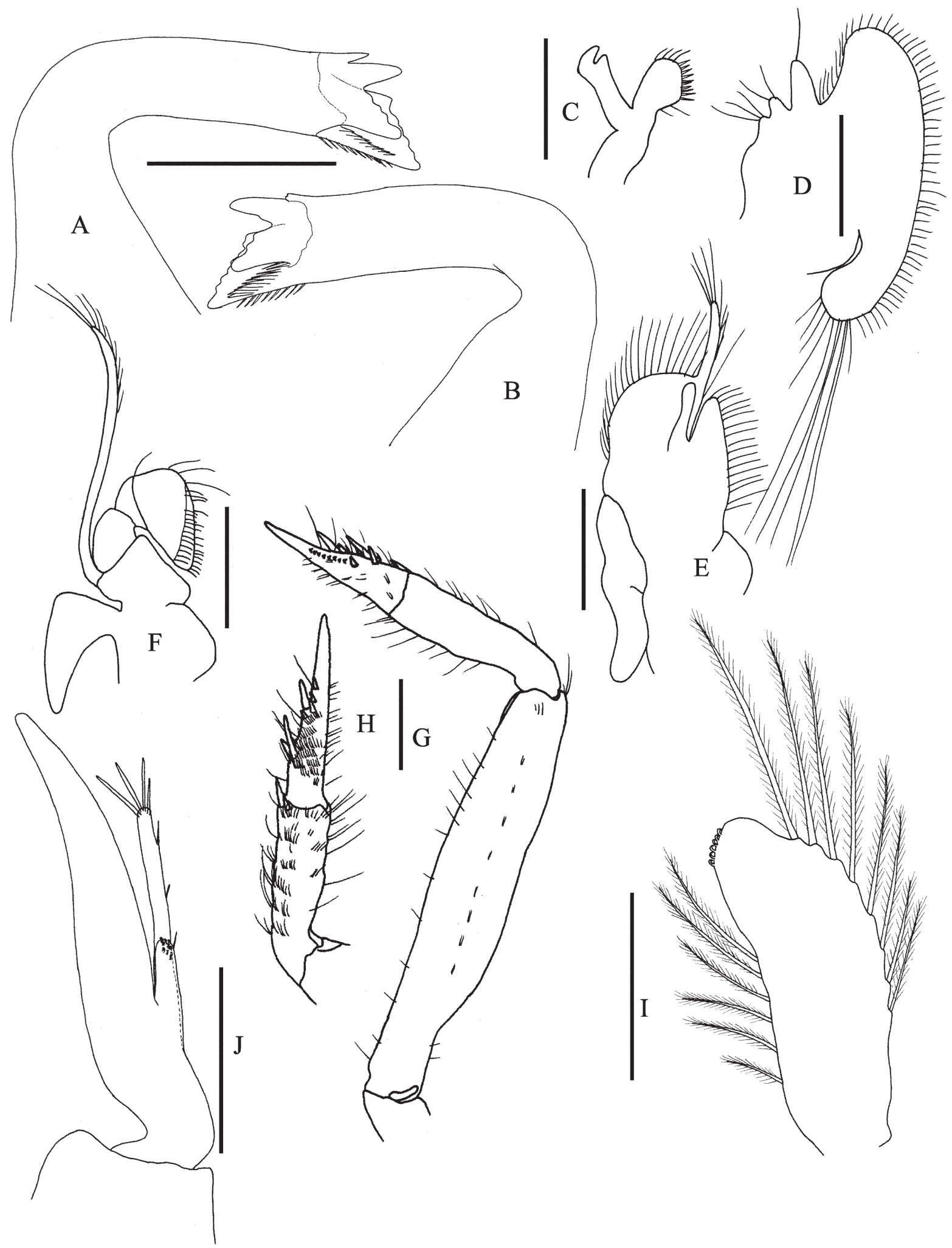

Figure 2. Processa hawaiensis, male 2.7 mm (EMU-9585). (A) Left mandible; (B) Right mandible; (C) Left maxillule; (D) Left maxilla; (E) Left first maxilliped; (F) Left second maxilliped; (G) Left third maxilliped; (H) Dactyl and propodus, left third maxilliped; (I) Endopod of right first pleopod; (J) Right second pleopod. Scale bars: A, B, I, 0.25 $\mathrm{mm}$; C-H, J, $0.5 \mathrm{~mm}$. 


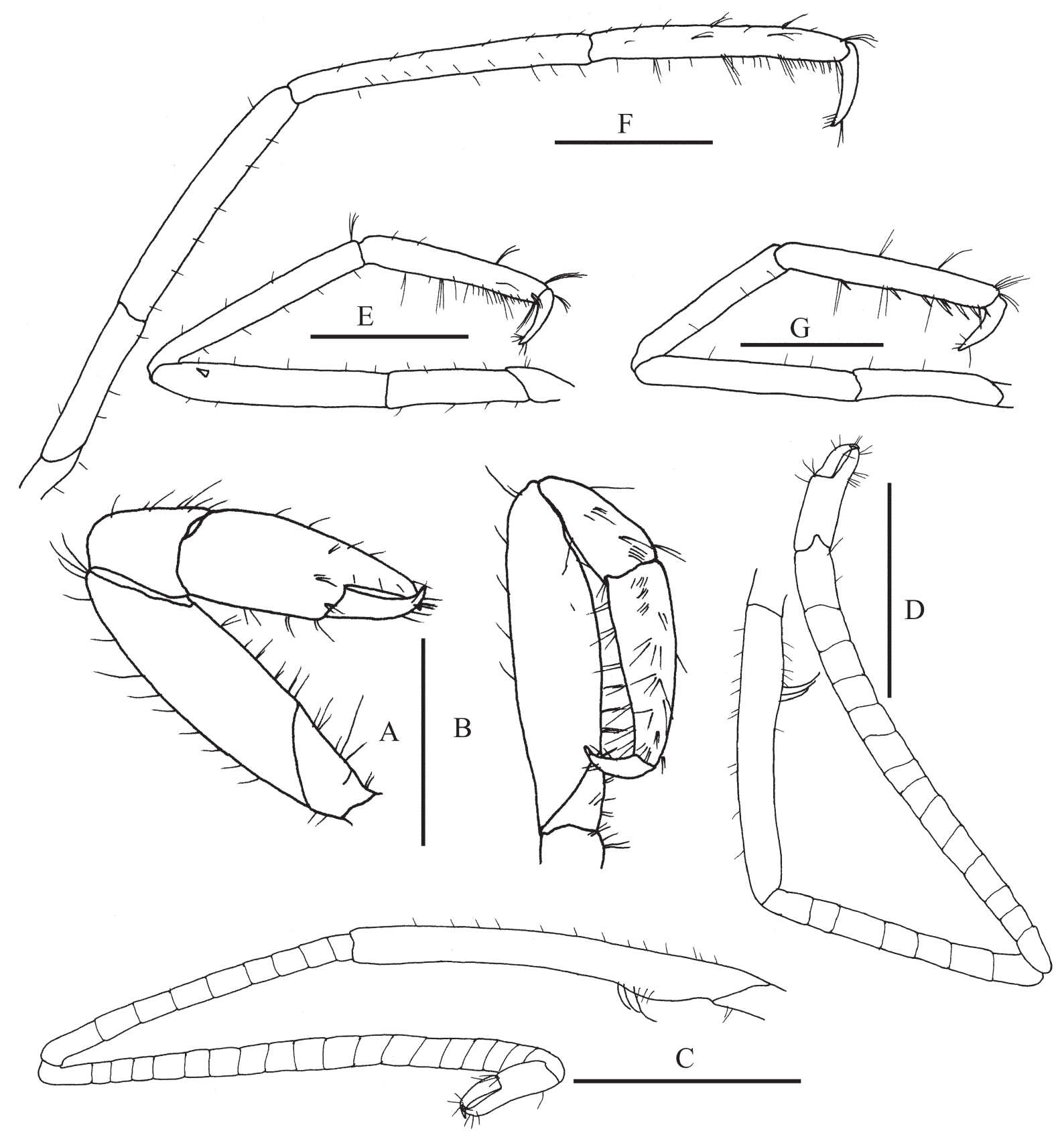

Figure 3. Processa hawaiensis, male $2.7 \mathrm{~mm}$ (EMU-9585). (A) Right first pereopod; (B) Left first pereopod; (C) Right second pereopod; (D) Left second pereopod; (E) Right third pereopod; (F) Right fourth pereopod; (G) Right fifth pereopod. Scale bar, $1 \mathrm{~mm}$.

Remarks: The fresh material from the Mexican Pacific examined herein differs in minor details from the description presented by Edmondson (1930) for P. paucirostris and from the redescription of $P$. hawaiensis by Hayashi (1975) (Table 1). In our specimens, the rostrum is short, triangular and the apex is simple, with 2 short subdistal setae. Edmondson (1930) described the rostrum as "shorter than eyes, straight, without keels, spines or hairs".
Hayashi (1975), who revised Edmondson's (1930) type material and additional material of P. hawaiensis from the Pacific Ocean and East Africa, reported a short rostrum, triangular in dorsal view, with a simple apex. However, a reexamination of the material reported by Álvarez et al. (1996) indicates that the rostrum bears two short subdistal setae (J.L. VillalobosHiriart, pers. comm., March 2012).

The presence of a pair of setae (in 
Table 1. Characters used in the original description and previous redescriptions of $P$. hawaiensis, and comparison with observations made using fresh material collected in Pacific western Mexico. ND, no data.

\begin{tabular}{|c|c|c|c|c|}
\hline Characters & Edmondson (1930) & Hayashi (1975) & Álvarez et al. (1996) & This study \\
\hline Rostrum & $\begin{array}{l}\text { Short, straigth, } \\
\text { without keels, } \\
\text { spines or hairs }\end{array}$ & $\begin{array}{l}\text { Short, triangular in } \\
\text { dorsal view; apex } \\
\text { simple }\end{array}$ & $\begin{array}{l}\text { Short, triangular in } \\
\text { dorsal view, with } 2 \\
\text { short subdistal setae; } \\
\text { apex simple }\end{array}$ & $\begin{array}{l}\text { Short, triangular in } \\
\text { dorsal view, with } \\
2 \text { short subdistal } \\
\text { setae; apex simple }\end{array}$ \\
\hline $\begin{array}{l}\text { Posterior margin of } \\
\text { telson }\end{array}$ & Three spines & $\begin{array}{c}\text { Three pairs of } \\
\text { spines }\end{array}$ & ND & $\begin{array}{c}\text { Three pair of spines } \\
\text { and one pair of } \\
\text { setae }\end{array}$ \\
\hline $\begin{array}{l}\text { Rigth carpus of } \\
\text { second pereopod }\end{array}$ & 18 articulations & $\begin{array}{c}15 \text { to } 18 \\
\text { articulations }\end{array}$ & 19 articulations & $\begin{array}{c}17 \text { to } 19 \\
\text { articulations }\end{array}$ \\
\hline $\begin{array}{l}\text { Right merus of } \\
\text { second pereopod }\end{array}$ & 8 articulations & 7 to 9 ariculations & 8 articulations & 7 to 9 articulations \\
\hline $\begin{array}{l}\text { Left carpus of } \\
\text { second pereopod }\end{array}$ & $\mathrm{ND}$ & $\begin{array}{c}10 \text { to } 14 \\
\text { articulations }\end{array}$ & 12 articulations & $\begin{array}{c}11 \text { to } 14 \\
\text { articulations }\end{array}$ \\
\hline $\begin{array}{l}\text { Leftt merus of } \\
\text { second pereopod }\end{array}$ & $\mathrm{ND}$ & 4 to 7 articulations & 7 articulations & 5 to 7 articulations \\
\hline $\begin{array}{l}\text { Ischium of second } \\
\text { pereopod }\end{array}$ & ND & $\begin{array}{l}\text { Divided in } 2 \\
\text { articulations }\end{array}$ & ND & $\begin{array}{l}\text { Divided in } 2 \\
\text { to } 3 \text { indistinct } \\
\text { articulations }\end{array}$ \\
\hline $\begin{array}{l}\text { Ischium of third } \\
\text { pereopod }\end{array}$ & $\mathrm{ND}$ & $\begin{array}{l}\text { Usually with a } \\
\text { single spine on } \\
\text { proximal third of } \\
\text { posterior margin }\end{array}$ & $\mathrm{ND}$ & Unarmed \\
\hline $\begin{array}{l}\text { Length proportion } \\
\text { of merus/carpus of } \\
\text { right cheliped }\end{array}$ & $\begin{array}{l}2 \text { times carpus } \\
\text { length }\end{array}$ & $\mathrm{ND}$ & $\begin{array}{l}2.2 \text { to } 2.6 \text { times } \\
\text { carpus length }\end{array}$ & $\begin{array}{l}\text { About } 2.5 \text { times } \\
\text { carpus length }\end{array}$ \\
\hline $\begin{array}{l}\text { Length proportion } \\
\text { of propodus/ } \\
\text { dactylus of fourth } \\
\text { pereopod }\end{array}$ & $\begin{array}{l}2 \text { times dactylus } \\
\text { length }\end{array}$ & $\begin{array}{l}\text { About } 3 \text { times } \\
\text { dactylus length }\end{array}$ & $\begin{array}{l}\text { More than } 3 \text { times } \\
\text { dactylus length }\end{array}$ & $\begin{array}{l}\text { About } 3 \text { times } \\
\text { dactylus length }\end{array}$ \\
\hline $\begin{array}{l}\text { Propodus of fifth } \\
\text { pereopod }\end{array}$ & $\mathrm{ND}$ & $\begin{array}{l}\text { Provided with } 9-12 \\
\text { spines on posterior } \\
\text { margin }\end{array}$ & $\mathrm{ND}$ & $\begin{array}{c}\text { Provided with } 9-12 \\
\text { spines on posterior } \\
\text { margin }\end{array}$ \\
\hline $\begin{array}{l}\text { Endopod of first } \\
\text { male pleopod }\end{array}$ & ND & $\begin{array}{l}\text { Broadened at apex; } \\
\text { outer margin with } \\
\text { long, plumose } \\
\text { setae; inner margin } \\
\text { with short setae }\end{array}$ & ND & $\begin{array}{l}\text { Tapering at apex; } \\
\text { outer and inner } \\
\text { margins with long, } \\
\text { plumose setae }\end{array}$ \\
\hline
\end{tabular}

addition to spines) on the posterior margin of telson was not reported by previous authors; however, presence of these in the material reported by Álvarez et al. (1996) was confirmed by J.L. Villalobos-Hiriart (pers. comm., March 2012). The number of articulations on the right and left carpus and merus of second pereopods seems to vary considerably (right: 15 to 18 and 7 to 9 , respectively; left: 10 to 14 and 4 to 7 , respectively; Table 1 ), but this is to be expected within the genus. Although it seems unlikely, Edmondson (1935: 5) reported an equal number of articulations
(11) in both the right and left carpi of the second pereopods. Hayashi (1975) indicated that the ischium of third pereopod usually bears a single spine on proximal third, but he also observed three specimens lacking that spine. In all the specimens examined during this study, the ischium was always unarmed. The merus of the right cheliped in the material examined is about 2.5 times longer than carpus. Edmondson (1930) reported a cheliped merus twice as long as the carpus. According to Álvarez et al. (1996), the merus of the right cheliped is 2.2 to 2.6 times the 
length of carpus. In the case of the material examined, the propodus of fourth pereopod is 3 times as long as dactylus, and only 2 times as long in the type of $P$. paucirostris (Edmondson, 1930). Álvarez et al. (1996) also indicated that the propodus of the fourth pair of pereopods is more than three times as long as the dactylus. Hayashi (1975) did not give proportions between the propodus and dactyl of third to fifth pereopod. However, based on one of the illustrations he provided, the relationship between propodus and dactyl of pereopods 3-5 is less than 3 to 1 . In the examined material, the first pair of pleopods bear long, plumose setae on both the outer and inner margins, and the apex is tapering, while in the material reported by Hayashi (1975) the apex is broad and the inner margin bears short (apparently non-plumose) setae.

Although these small differences might not be sufficient to justify recognition of a distinct species in the eastern Pacific, they seem to justify a thorough revision of material of $P$. hawaiensis throughout its currently recognized distribution range, including an analysis of their relationships based on molecular data.

Processa peruviana Wicksten, 1983 Processa sp.- Méndez, 1981: 98, fig. 294.Processa peruviana Wicksten, 1983: 29, figs. 4-6.- Hendrickx and Wicksten, 1987: 15.Wicksten and Hendrickx, 1992: 9 (list); 2003: 68 (list).- Montagne and Cadien, 2001: 202.Hendrickx and Wicksten, 2011: 31.- De Grave and Fransen, 2011: 439 (list).

Material examined: 2 females 8.2$8.7 \mathrm{~mm}$, TALUD XIV, St. $1 \quad\left(28^{\circ} 15^{\prime} 38^{\prime \prime} \mathrm{N}\right.$ - 111 $\left.{ }^{\circ} 58^{\prime} 33^{\prime \prime W}\right), 208-212 \mathrm{~m}$, benthic sledge (EMU-9506A); 1 male $8.3 \mathrm{~mm}$, TALUD XIV, St. 7 (2815'27”N - 112'39'36”W), 203-204 m, Agassiz dredge (EMU-9506B).

Remarks: As noted by Hendrickx and Wicksten (2011), P. peruviana is widely distributed throughout the eastern tropical Pacific. The specimens were collected in the following environmental conditions: muddy bottom; epibenthic water temperature and dissolved oxygen, $12.2-12-7^{\circ} \mathrm{C}$ and 0.46 and $2.18 \mathrm{ml} \mathrm{O}_{2} / \mathrm{l}$, respectively.

\section{Key to species of Processa from the eastern Pacific}

1. Pereopods 2 equal in length, carpus with 9-11 articles. Rostrum narrow, slender, bifid at apex Processa aequimana - Pereopods 2 not equal in length, right longer than left. Rostrum short, apex simple..............2

2. Right carpus with 17-19 articles. Propodus of pereopods 5 with spines on flexor margin. Exopod of third maxilliped rudimentary ..................... Processa hawaiensis - Right carpus with 49-55 articles. Propodus of pereopods 5 without spines on flexor margin. Exopod of third maxilliped well developed Processa peruviana

\section{Acknowledgments}

The authors thanks all colleagues, students and crew members for their help during sampling activities aboard the $\mathrm{R} / \mathrm{V}$ "El Puma" during the TALUD XIV cruise, and Nuria Méndez Ubach, Mercedes Cordero Ruiz, Carmen Espinosa Pérez, José Salgado Barragán, Pablo Zamorano, Dafne Bastida Izaguirre, Cristian Galvan Villa and Arizbeth Alonso Dominguez for their assistance during the sampling trips to Sonora, Nayarit, and Jalisco. Our sincere thanks to J.L. VillalobosHiriart, Collección Nacional de Crustáceos, UNAM, Mexico D.F., for providing information related to specimens held in the collection. MAP thanks CONACYT, Mexico, for the grant received during his postdoctoral stay at CUCBA, Universidad de Guadalajara, Jalisco.

\section{References}

Álvarez, F., Camacho, M.E. and Villalobos, 
J.L. 1996. The first species of Prionalpheus from the eastern Pacific, and new records of caridean shrimp (Crustacea: Decapoda: Caridea) from the western coast of Mexico. Proceedings of the Biological Society of Washington, 109(4): 715-724.

Chace, F.A., Jr. 1962. The non-brachyuran decapod crustaceans of Clipperton Islands. Proceedings of the United States National Museum, 113(3466): 605-634.

Dana, J.D. 1852. Conspectus Crustaceorum quae in Orms Terrarum circumnavigatione, Carolo Wilkes e Classe Republicae Foederatae duce, lexit et descripsit. Proceedings of the Academy of Natural Sciences of Philadelphia, 1852: 10-28.

Dana, J.D. 1852a. Crustacea. United States Exploring Expedition during the years 1838, $1839,1840,1841,1842$ under the command of Charles Wilkes, U.S.N., 13, 1-1620.

Dana, J.D. 1855. Crustacea. United States Exploring Expedition during the years 1838, $1839,1840,1841,1842$ under the command of Charles Wilkes, U.S.N., 13, atlas, 1-27, pls.1-96.

De Grave, S. and Fransen, C.H.J.M. 2011. Carideorum Catalogus: The recent species of the Dendrobranchiate, Stenopodidean, Procarididean and Caridean shrimps (Crustacea: Decapoda). Zoologische Mededelingen, 89(9): 195-589.

Edmondson, C.H. 1930. New Hawaiian Crustacea. Bishop Museum Occasional Papers, IX(10), 3-18.

Edmondson, C.H. 1935. New and rare Polynesian Crustacea. Bishop Museum Occasionals Papers, X(24): 1-40, pls.1, 2.

Edmondson, C.H. 1946. Reef and shore fauna of Hawaii. Special Publication, B. P. Bishop Museum, 22: 1-381.

Garth, J.S. 1946. Distribution studies of Galapagos Brachyura. Allan Hancock Pacific Expeditions, 5(11): 603-638.

Gurney, R. 1937. Notes on some decapod Crustacea from the Red Sea. I. The genus Processa. Proceedings of the Zoological Society of London, 1937: 85-101, pls. 1-6.

Hayashi, K.I. 1975. The Indo-West Pacific Processidae (Crustacea, Decapoda,
Caridea). Journal of the Shimonoseki University of Fisheries, 24: 47-145.

Hendrickx, M.E. 1992. Distribution and zoogeographic affinities of decapod crustaceans of the Gulf of California, Mexico. Proceedings of the San Diego Society of Natural History, 20: 1-11.

Hendrickx, M.E. 1995. Checklist of brachyuran crabs (Crustacea: Decapoda) from the Eastern Tropical Pacific. Bulletin de l'Institut royal des Sciences naturelles de Belgique, 65: 125-150.

Hendrickx, M.E. 2012. Distribution and abundance of the pelagic processid, Processa pippinae Wicksten and Méndez, 1985 (Decapoda, Caridea, Processidae), collected during the TALUD XIV cruise in the Gulf of California, Mexico, and description of a new genus. Crustaceana, 85(4-5): 463-472.

Hendrickx, M.E. e M.K. Wicksten. 1987. Estudos da fauna marinhas costeiras do sul de Sinaloa, no México. VIII. Relatório adicional sobre os crustáceos carídeos. Anales del Instituto de Ciencias del Mar y Limnología, UNAM, 14 (1): 13-20.

Hendrickx, M.E. and Wicksten, M.K. 2011. New distribution ranges and records of carideans shrimps (Crustacea: Decapoda: Caridea) from the west coast of Mexico. Hidrobiologica, 21(1): 26-33.

Man, J.G. de 1920. The Decapoda of the Siboga Expedition, Part W. Families Pasiphaeidae, Stylodactylidae, Hoplophoridae, Nematocarcinidae, Thalassocaridae, Pandalidae, Psalidopodidae, Gnathophyllidae, Processidae, Glyphocrangonidae and Crangonidae. Siboga Expedition, Monography, 39a: 1-318, pls. $1-25$.

Manning, R.B. and Chace, Jr. F.A. 1971. Shrimps of the family Processidae from the norhwestern Atlantic Ocean (Crustacea: Decapoda: Caridea). Smithsonian Contributions to Zoology, 89: 1-49.

Manning, R.B. and Hart, C.W.J. 1991. A new species of Processa from Bermuda (Crustacea: Decapoda: Caridea). Proceedings of the Biological Society of Washington, 104: 317-321.

Méndez, M. 1981. Claves de identificación y 
distribución de los langostinos y camarones (Crustacea: Decapoda) del mar y ríos de la costa del Perú. Boletín del Instituto del Mar del Perú, 5: 1-170.

Montagne, D.E. and Cadien, D.B. 2001. Northern range extensions into the southern California Bight of ten decapod Crustacea related to the 1991/92 and $1997 / 98$ El Niño events. Bulletin of the Southern California Academy of Sciences, 100(3): 199-211.

Rathbun, M.J. 1903. The Brachyura and Macrura of the Hawaiian Islands. Bulletin of the United States Fish Commission, 23(3): 827-930, pls. 3-24.

Weitenweber, W.R. 1854. Aus James DANA'S Conspectus of the Crustacea, Lotos Praha, 4, 5-14, 35-38, 60-63, 107-115, 153-157, 251-254.

Wicksten, M. K. 1983. A monograph on the shallow water caridean shrimps of the Gulf of California, Mexico. Allan Hancock Monographs in Marine Biology, Allan Hancock Foundation, 13: 1-59.

Wicksten, M.K. and Hendrickx, M.E. 1992. Checklist of Penaeoid and Caridean shrimps (Decapoda: Penaeoidea, Caridea) from the eastern tropical Pacific. Proceedings of the San Diego Society of Natural History, 9: 1-11.

Wicksten, M.K. and Hendrickx, M.E. 2003. An updated checklist of benthic marine and brackish water shrimps (Decapoda: Penaoidea, Stenopodidea, Caridea) from the Eastern Tropical Pacific. p. 49-76. In: Hendrickx M.E. (ed), Contributions to the Study of East Pacific Crustaceans 2. [Contribuciones al Estudio de los Crustáceos del Pacífico Este 2] Instituto de Ciencias del Mar y Limnología, UNAM.

Wicksten, M.K. and Méndez, M.G. 1985. Processa pippinae, a new species of deepsea shrimp from the Gulf of California (Decapoda, Caridea). Crustaceana, 49: 1621. 